\title{
The interannual variability of Africa's ecosystem productivity: a multi-model analysis
}

\author{
U. Weber ${ }^{1,2}$, M. Jung ${ }^{2}$, M. Reichstein ${ }^{2}$, C. Beer ${ }^{2}$, M. C. Braakhekke ${ }^{2}$, V. Lehsten ${ }^{3}$, D. Ghent ${ }^{4}$, J. Kaduk $^{4}$, N. Viovy ${ }^{5}$, \\ P. Ciais ${ }^{5}$, N. Gobron ${ }^{6}$, and C. Rödenbeck ${ }^{2}$ \\ ${ }^{1}$ Department of Forest Science and Environment,University of Tuscia, Viterbo, Italy \\ ${ }^{2}$ Max Planck Institute for Biogeochemistry, Jena, Germany \\ ${ }^{3}$ GeoBiosphere Science Centre, Lund University, Sweden \\ ${ }^{4}$ Department of Geography, University of Leicester, UK \\ ${ }^{5}$ Laboratoire des Sciences du Climate et de l' Environnement, Gif-sur-Yvette, France \\ ${ }^{6}$ European Commission - DG Joint Research Centre, Institute for Environment and Sustainability, Global Environment \\ Monitoring Unit, Ispra (VA), Italy
}

Received: 4 August 2008 - Published in Biogeosciences Discuss.: 10 October 2008

Revised: 2 February 2009 - Accepted: 17 February 2009 - Published: 25 February 2009

\begin{abstract}
We are comparing spatially explicit processmodel based estimates of the terrestrial carbon balance and its components over Africa and confront them with remote sensing based proxies of vegetation productivity and atmospheric inversions of land-atmosphere net carbon exchange. Particular emphasis is on characterizing the patterns of interannual variability of carbon fluxes and analyzing the factors and processes responsible for it. For this purpose simulations with the terrestrial biosphere models ORCHIDEE, LPJDGVM, LPJ-Guess and JULES have been performed using a standardized modeling protocol and a uniform set of corrected climate forcing data.

While the models differ concerning the absolute magnitude of carbon fluxes, we find several robust patterns of interannual variability among the models. Models exhibit largest interannual variability in southern and eastern Africa, regions which are primarily covered by herbaceous vegetation. Interannual variability of the net carbon balance appears to be more strongly influenced by gross primary production than by ecosystem respiration. A principal component analysis indicates that moisture is the main driving factor of interannual gross primary production variability for those regions. On the contrary in a large part of the inner tropics radiation appears to be limiting in two models. These patterns are partly corroborated by remotely sensed vegetation properties from the SeaWiFS satellite sensor. Inverse atmospheric modeling
\end{abstract}

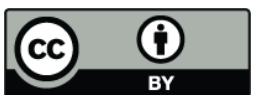

Correspondence to: $\mathrm{U}$. Weber (uweber@bgc-jena.mpg.de) estimates of surface carbon fluxes are less conclusive at this point, implying the need for a denser network of observation stations over Africa.

\section{Introduction}

Understanding terrestrial sources and sinks of $\mathrm{CO}_{2}$ and its variability is important for understanding the carbon cycleclimate feedback. Extensive research in this field has concentrated on the highly developed parts of the world, in particular North America and Europe with a strong research infrastructure. In a recent review, Williams et al. (2007) identified Africa as "one of the weakest links in our understanding of the global carbon cycle." Africa is the second largest continent of the world occupying about $20 \%$ of global land mass and inhabits a large variety of ecosystems ranging from perhumid tropical forest to semi-arid and arid grass and shrub communities. Although Africa's decadal scale mean carbon balance appears to be neutral, the continent contributes about half of the interannual variability of the carbon balance on global scale (Williams et al., 2007). This large interannual variability results primarily from climatic perturbations related to the El Nino phenomenon that directly affects the ecosystems' productivity and due to concomitant biomass burning (e.g. Le Page et al., 2007; Anyamba et al., 2002, 2003; Myneni et al., 1996; Kogan 2000).

Given the scarcity of observation sites for atmospheric $\mathrm{CO}_{2}$ concentrations and land - atmosphere $\mathrm{CO}_{2}$ exchange the uncertainties of African carbon cycle research remain

Published by Copernicus Publications on behalf of the European Geosciences Union. 
high in particular regarding the spatial localization of hotspot regions of variability and the underlying driving forces. Simulations of terrestrial ecosystem models can provide insights here; however, these models are also associated with large uncertainties (e.g. McGuire et al., 2001; Friedlingstein et al., 2006) in particular for water limited conditions (e.g. Morales et al., 2005; Jung et al., 2007), and in addition have generally not been tested and parameterized specifically for Africa. Thus, confidence of a single model analysis is limited and a multi-model study is warranted to identify coherent and dissimilar behavior between different biosphere models.

In this study we assess the interannual variability of Africa's carbon cycle using four different terrestrial carbon cycle models in conjunction with remotely sensed indicators for the state of the vegetation as well as carbon balance estimates from global atmospheric inversions. We aim to identify (1) regions of largest carbon balance interannual variability, (2) the primary process (photosynthesis or respiration) dominating the carbon balance variability, and (3) which climate variables are driving the ecosystem's carbon cycle in the models.

\section{Materials and methods}

\subsection{Model descriptions}

The four ecosystem models ORCHIDEE (Krinner et al., 2005), LPJ-DGVM (Sitch et al., 2003), LPJ-GUESS (Smith et al., 2001), and JULES/TRIFFID (Cox et al., 2001; Essery et al., 2001; Hughes et al., 2006) applied in this study are coupled biogeography-biogeochemistry models, i.e. they combine representations of both vegetation dynamics and land-atmosphere carbon and water exchanges (dynamic global vegetation models - DGVMs). The concept of plant functional types (PFT) (Smith et al., 1997) is used to discretize differences in physiology and allometry of species including adaptations to climatic conditions and disturbance regime. PFTs compete for resources like light, and water. Representations of vegetation structure like allometry, and function like phenology, allocation, mortality, and establishment are essential for this. Gross primary production (GPP) is calculated based on a coupled photosynthesis-water balance scheme after (Farquhar et al., 1980; Collatz et al., 1991, 1992), where simplifications have been incorporated in the different models as described in detail in the above references. Heterotrophic respiration is assumed to be represented by first-order decay of organic material with decay rates for a few pools (Foley, 1995) which depend on temperature and moisture following (Lloyd and Talor, 1994) or a $\mathrm{Q}_{10}$ formula. Fire, the main disturbance in the region is simulated following (Thonicke et al., 2001) within LPJ-DGVM, ORCHIDEE, and LPJ-GUESS.

The applied models differ in the temporal resolution and in the resolution of vegetation structure representations. While
LPJ-DGVM and LPJ-GUESS are designed as stand-alone models running on a daily time step, ORCHIDEE and JULES can be coupled to General Circulation Models functioning as land-surface schemes. Therefore, latter models resolve the diurnal cycle with time steps of 30 to $60 \mathrm{~min}$. Usually, the LPJ family of models is driven by monthly climatic data which are interpolated to pseudo-daily using a whether generator for precipitation. In this study, the LPJ-DGVM is driven by daily climatic inputs. In doing so, net radiation is approximated from global radiation after Linacre (1969). The LPJ-GUESS has the most advanced representation of vegetation structure including age with features of a forestgap model (Shugart, 1984) resolving forest succession. LPJDGVM and ORCHIDEE have intermediate complexity applying the concept of "average individuals" for a whole grid cell (Sitch et al., 2003) while JULES/TRIFFID employs a heuristic approach to determine the vegetation coverage and carbon allocation to each PFT.

\subsection{Model drivers}

All models are driven by the same climate data, atmospheric $\mathrm{CO}_{2}$ concentration, and soil texture type on a $1^{\circ}$ grid from 1982 to 2006, which has been derived as follows: Meteorological forcing (near surface air temperature, specific humidity, wind speed, radiation, and precipitation) originates from 6-hourly NCEP-DOE Reanalysis-2 (Kanamitsu et al., 2002) that were spatially interpolated to $1^{\circ}$ from the original T62 Gaussian grid. Despite substantial improvements of NCEP R2 over R1 considerable precipitation biases remain in comparison to various independent data sets (Fekete et al., 2004). To account for these limitations, precipitation was corrected using more reliable data sets based on observations from the satellite based Tropical Rainfall Measuring Mission (TRMM 3B43) available from 1998-2006 (Kummerow et al., 1998) and from interpolated station data provided by the Climate Research Unit (CRU) from 1961-2003 (CRUTR2.1, Mitchell and Jones, 2005). The general calibration method follows Williams et al. (2008), Ngo-Duc et al. (2005) and Sheffield et al. (2006), where the daily values of the original NCEP data for each grid cell are scaled to match in their monthly totals those of the corresponding CRU and TRMM data. For the CRU period (1979-1997) precipitation was corrected following:

$$
\begin{aligned}
\mathrm{CAl}_{\mathrm{N}} \mathrm{NCEP}_{\mathrm{y}, \mathrm{m}, \mathrm{d}, \mathrm{h}}= & \frac{\operatorname{NCEP}_{\mathrm{y}, \mathrm{m}, \mathrm{d}, \mathrm{h}} \times \mathrm{CRU}_{\mathrm{y}, \mathrm{m}}}{\mathrm{NCEP}_{\mathrm{y}, \mathrm{m}}} \times \\
& \frac{\sum_{1998}^{2006} \mathrm{TRMM}_{\mathrm{m}}}{\sum_{1998}^{2006} \mathrm{CRU}_{\mathrm{m}}}
\end{aligned}
$$

For the TRMM period (1998-2006) the calibration used:

$\mathrm{CAl}_{-} \mathrm{NCEP}_{\mathrm{y}, \mathrm{m}, \mathrm{d}, \mathrm{h}}=\mathrm{NCEP}_{\mathrm{y}, \mathrm{m}, \mathrm{d}, \mathrm{h}} \times \frac{\mathrm{TRMM}_{\mathrm{y}, \mathrm{m}}}{\mathrm{NCEP}_{\mathrm{y}, \mathrm{m}}}$ 


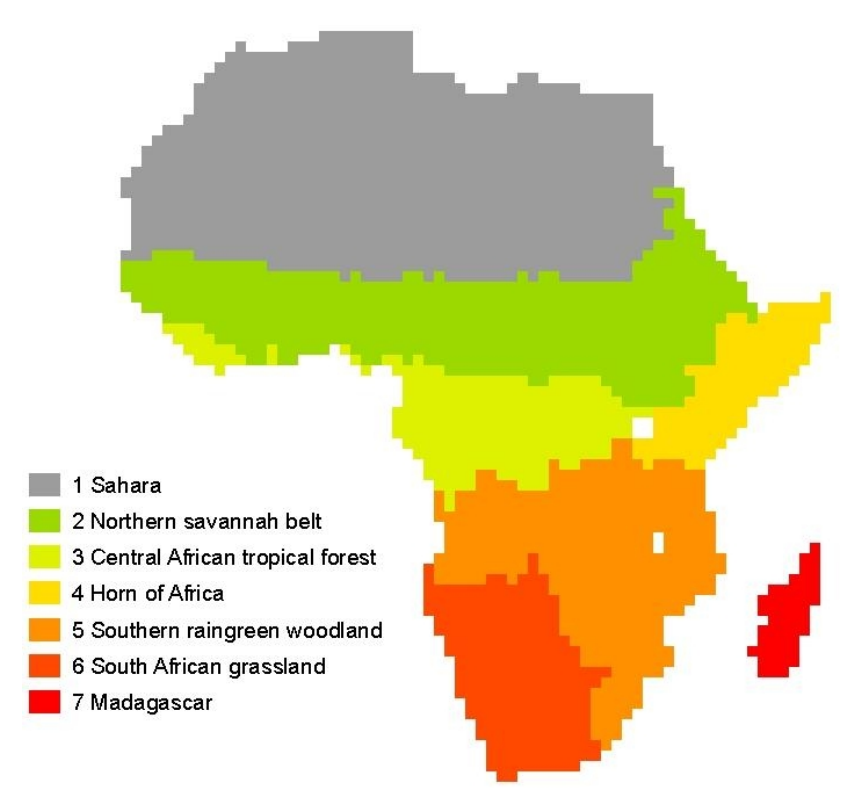

Fig. 1. African ecoregions

The adjustment yielded an overall reduction of $15.2 \%$ precipitation.

Soil texture is given by the IGBP-DIS map at $1^{\circ}$ (Tempel et al., 1996). Data on the annual $\mathrm{CO}_{2}$ concentration was taken from measurements at Mauna Loa (www.esrl.noaa.gov/gmd/ $\operatorname{ccgg} /$ trends/).

\subsection{Experimental setup}

The simulation of the terrestrial carbon and water budgets are carried out at a spatial resolution of $1^{\circ} \times 1^{\circ}$ for entire continental Africa for the target period 1982-2006. Spin-up calculations were performed by repeating the years 1982-1992 using the meteorological data sets of the appropriate years and a fixed $\mathrm{CO}_{2}$ concentration of 341.13 ppm (Mauna Loa value in 1982) until carbon pools reach equilibrium. After the spin-up, model simulations start in 1982 with rising $\mathrm{CO}_{2}$ concentration per annum. Potential vegetation distribution was dynamically simulated by the models.

\subsection{Data analysis}

\section{Definition of regions}

We define six major regions of sub-saharan Africa based on the broad distribution of ecosystem types (available from global land cover maps), and thus implicitly according to bioclimatic conditions: Northern Savannah Belt, Central African tropical forest, Horn of Africa, Southern raingreen woodlands, South African grasslands, and Madagascar (Fig. 1). Given that Madagascar is small in comparison to the other regions and very heterogeneous we do not discuss this region extensively.

\section{Quantification of interannual variability}

Interannual variability (IAV) is calculated for each pixel and model as the standard deviation of the respective quantity (e.g. GPP) for a yearly time step across all years, resulting in a grid of IAV for each model and variable. For identifying spatial patterns of relatively high and low interannual variability, the IAV grid of each model was z-transformed.

$\mathrm{z}\left(\mathrm{IAV}_{\mathrm{i}}\right)=\frac{\left(\mathrm{IAV}_{\mathrm{i}}-\overline{\mathrm{IAV}}\right)}{\sigma_{\mathrm{IAV}}}$

Where $\mathrm{z}\left(\mathrm{IAV}_{\mathrm{I}}\right)$ is the standardized IAV of grid cell $\mathrm{i}, \overline{\mathrm{IAV}}$ and $\sigma_{\text {IAV }}$ are the spatial mean and standard deviation of the IAV, respectively. Hence $\mathrm{z}\left(\mathrm{IAV}_{I}\right)$ measures the degree of variability for each pixel in units of standard deviations, i.e. values larger than 0 refer to above average interannual variability and for example a value of two indicates variability of 2 standard deviations above the mean variability of the continent. Consistent spatial patterns between all models are defined as model agreement and are implemented as the sum of models per grid cell which show variability larger than one standard deviation above the mean variability of the continent.

\section{Principal component analysis}

To analyze the relationship between meteorological conditions and simulated carbon fluxes on annual scale we follow the approach of Jung et al. (2007). First we reduce the array of several meteorological driver variables to their principal components and then calculate the correlation between meteorological principal components and relative flux variations for each grid cell. The principal component analysis (PCA) of the meteorological data reduces the dimensionality of the data set and often extracts major weather patterns or gradients. We used four annual data fields as input to the PCA: precipitation, air temperature, radiation, specific air humidity.

\section{Corroboration against satellite data}

We use the fraction of absorbed photosynthetic active radiation (FAPAR) product of Gobron et al. (2006) based on the SeaWiFS satellite sensor as a proxy for vegetation productivity (available at: www.fapar.jrc.it). It has been designed as an optimized indicator for the state and health of the vegetation and overcomes several limitations of the classically used normalized difference vegetation index (NDVI) (Gobron et al., 2000). Jung et al. (2008) have shown that the annual sum of FAPAR growing season values correlates strongly with annual gross primary production from eddy covariance measurement sites in Europe. At first glance it appears to be more consistent to compare simulated FAPAR by the models with the FAPAR satellite retrievals instead of using the FAPAR as 
a proxy for GPP. However, there are several reasons why it makes more sense to interpret the remotely sensed FAPAR as an indicator for productivity: (1) ecosystem models tend to capture interannual variability of GPP primarily via interannual variations of radiation use efficiency and not via changes of leaf area (Jung et al., 2007) while the interannual anomaly patterns of the SeaWiFS-FAPAR provide a realistic picture of the GPP anomalies (Jung et al., 2008; Gobron et al., 2005), and (2) there are conceptual mismatches between the FAPAR from the satellite and the FAPAR simulated by models. For example the response of herbaceous understorey, which is very sensitive to e.g. water stress, plays likely an important role in the anomaly patterns of the satellite FAPAR by indicating the direction of change of the ecosystem (see in Jung et al., 2008 for more discussion). In addition, changes of the remotely sensed FAPAR may originate from changes of leaf colour (e.g. leaf darkening or yellowing), which indicates changes of chlorophyll content and thus radiation use efficiency. In contrast, the leaves in the models do not change their reflective properties; effects of leaf aging on photosynthesis are in some cases captured as Vcmax being a function of leaf age as in ORCHIDEE.

We calculate mean annual FAPAR as a proxy for GPP after filling gaps of the FAPAR time series as described in Jung et al. (2008). In addition we compare the mean seasonal cycles of simulated GPP and remotely sensed FAPAR for the defined regions.

\section{Comparison with atmospheric inversions}

We compare the simulated variations of the African carbon balance in terms of Net Ecosystem Productivity (NEP), and Net Biome Production (NBP) with results from global atmospheric inversions from Rödenbeck (2005) (version s96_v3.1) covering the period of 1997 to 2006 based on globally 51 stations of atmospheric $\mathrm{CO}_{2}$ records. This way we also determine the role of fire on the interannual variability of the carbon balance. Simulated NEP is calculated as GPP minus Terrestrial Ecosystem Respiration (TER). Modeled NBP is based on the difference of NEP and model specific fire emissions, except JULES which does not include fire. The inversions detect carbon emissions from fire. To facilitate comparability between NEP simulations and inversions, we used the Global Fire Emission Database (GFED version 2.1, available at: ftp://daac.ornl.gov/data/global_vegetation/ fire_emissions_v2.1) from Randerson et al. (2007) and Van der Werf et al. (2006) to correct for carbon fire emissions in the atmospheric inversions.
Table 1. Continental annual average GPP, NPP per model (temporal standard deviation), all numbers are in $\mathrm{Pg} \mathrm{C}$-1

\begin{tabular}{lllll}
\hline & LPJ_DGVM & LPJ_GUESS & JULES & ORCHIDEE \\
\hline GPP & $39.68[1.73]$ & $16.58[1.04]$ & $31.50[0.91]$ & $29.80[1.20]$ \\
NPP & $17.28[1.12]$ & $9.16[0.67]$ & $12.01[0.48]$ & $15.38[0.77]$ \\
\hline
\end{tabular}

\section{Results and discussion}

\subsection{Mean annual carbon fluxes}

We use annual sums of GPP and Net Primary Production (NPP) over the entire study period to investigate the mean annual carbon fluxes at the continental as well as on the regional scale, and compare them to global numbers based on the IPCC Fourth Assessment Report (IPCC 2007). Modelled absolute NEP estimates strongly depend on factors that cannot be taken into account (e.g. change in land-use history) and thus are relatively meaningless. Hence, we discuss NEP only in terms of interannual variability as previously done in other contexts (e.g., Ciais et al., 2005; Vetter et al., 2008) (see below). At continental scale annual GPP estimates range from 16.58 to $39.68 \mathrm{Pg} \mathrm{C} \mathrm{y-1} \mathrm{(14-33 \%}$ of global GPP (120 Pg C y-1)), and 9.16 to $17.28 \mathrm{Pg} \mathrm{C} \mathrm{y-1}$ for NPP (14-27\% of global NPP (65 Pg C y-1)) respectively (Table 1). Previous modeling studies indicated mean annual NPP between 7 and 13 Pg C y-1 (Cramer et al., 1999; Cao et al., 2001; Potter, 2003). Possibly, the too extensive forest cover simulated by LPJ-DGVM (17.28 Pg C y-1) and ORCHIDEE (15.38 Pg C y-1) may have caused an overestimation of continental scale NPP. A realistic representation of savannah ecosystems is still a challenge for dynamic vegetation models.

The comparison of simulated interannual variations of the African carbon balance with atmospheric inversions reveals a consistent pattern but some discrepancies remain (Fig. 2). There is agreement of above average net uptake for 1997, 2000, 2001, and 2006 and a below average carbon balance for 1998, 2002, 2003 and 2005. The general pattern of continental scale IAV is consistent between NEP and NBP, which indicates a small contribution of fire emissions on the variability of the African carbon balance in the considered period. Relatively low interannual variability of fire emissions in Africa is consistent with van der Werf et al. (2006). Some of the deviations between the models and the inversions is certainly also related to uncertainties of the latter given that the density of atmospheric $\mathrm{CO}_{2}$ measurement stations is low.

Differences between models are even more pronounced at regional level (Fig. 3). GPP numbers are similar between JULES, ORCHIDEE, and LPJ-DGVM for the Northern Savannah Belt, the Central Tropical Forest, and the Southern Raingreen Woodland, where LPJ-Guess represents only 50 percent of other modeled GPP numbers. GPP estimates for 


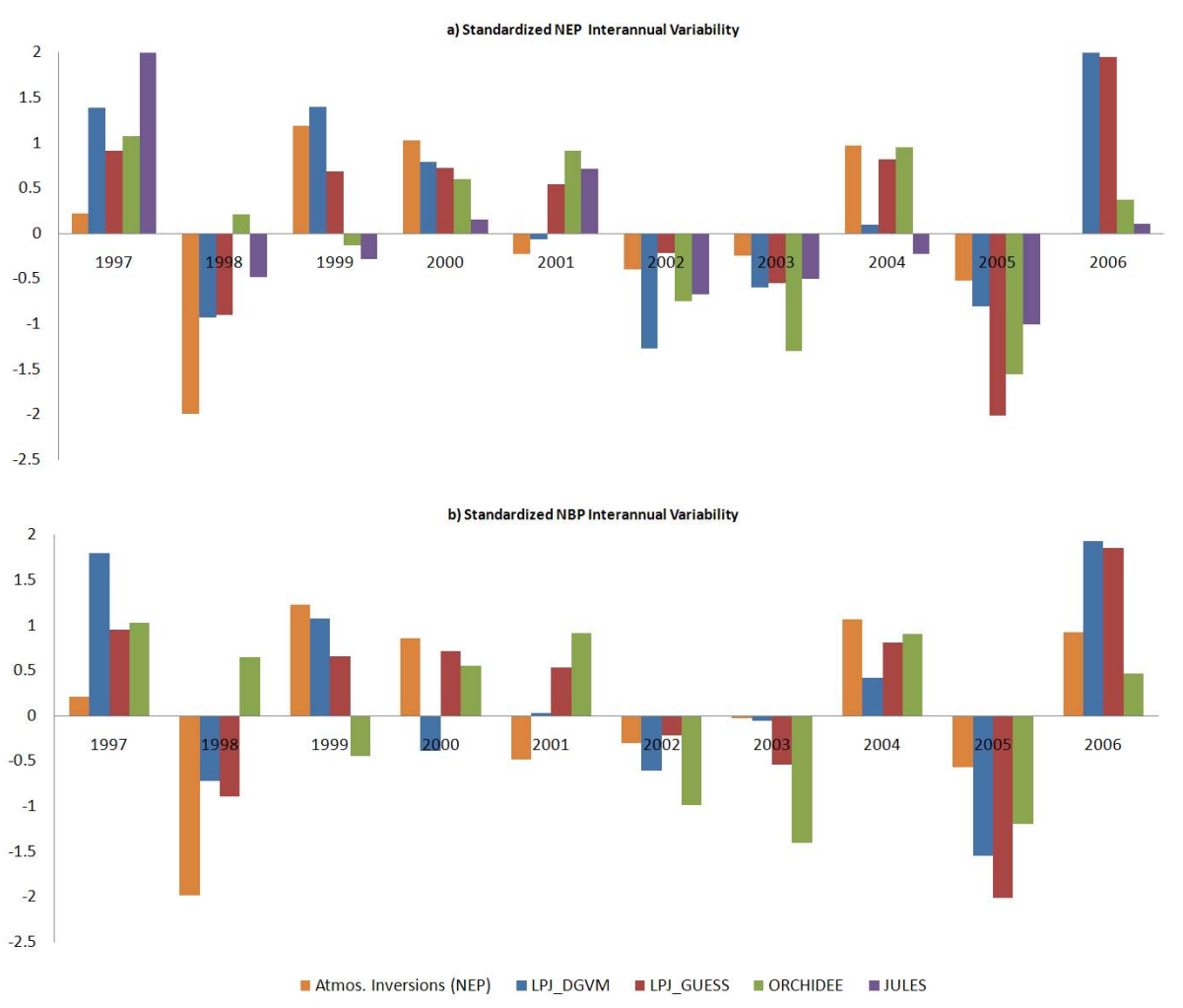

Fig. 2. Comparison of Atmospheric Inversion and Models based on standardized NEP(a) and NBP(b) (1997-2006). Due to the standardization method, 0 represents the mean of each individual distribution, but no neutral balance. NEP for models was calculated as the difference of GPP and TER. NEP from atmospheric inversions was calculated by removing fire emissions using GFED (van der Werf et al., 2006). NBP refers to the originally inversion results, and NEP minus model specific fire emissions (except JULES, which does not simulate fire).

the Horn of Africa and the South African Grassland are consistent between JULES and LPJ-DGVM, but significantly lower for ORCHIDEE but in the same range as LPJ-Guess. Annual NPP estimates are more consistent between all models. Exceptions are lower LPJ-Guess NPP at the Northern Savannah Belt, twice as much higher ORCHIDEE NPP than inter-model average at the Central Tropical Forest, as well as a high and low plateau situation in the South African Grassland region as represented by JULES/LPJ-DGVM and ORCHIDEE/LPJ-GUESS.

Despite the discrepancies among models regarding the absolute flux magnitudes, consistent patterns emerge between models and with satellite observations regarding seasonal changes of photosynthesis in the different regions (Fig. 4). Both, remotely sensed FAPAR and simulated GPP show that the seasonality of photosynthesis varies in concert with rainfall in all regions except for the inner tropical forest, where low intra-annual variation of rainfall creates climatic conditions without water limitation, reducing the effect of precipitation on photosynthesis. The heterogeneous vegetation of Madagascar together with known extensive anthropogenic transformations (Green and Sussman, 1990) are likely a major reason for the disagreement between the models and between models and remotely sensed FAPAR.

\subsection{Regions of large interannual variability}

Similar spatial patterns of interannual variability for GPP and NEP are estimated by all models (Fig. 5). Despite some differences of the patterns among the models, we can identify areas of large interannual variability of GPP and NEP in east and south Africa predicted by all models (Fig. 6). Both regions are dominated by herbaceous vegetation, including extensive agricultural land, and are known to be strongly influenced by El Nino conditions (Plisnier et al., 2003; Kogan, 2000). The independent remote sensing based FAPAR data confirms these two variability hotspot regions (Fig. 7). However, ORCHIDEE and JULES further simulate considerable variability in the northern savannahs and partly in the tropical forest, which is not evident in the satellite observations.

\subsection{What drives NEP interannual variability - Photosyn-} thesis or respiration?

The previous section indicated that regions of large interannual NEP variability are associated with also large GPP variability, suggesting that variations of photosynthesis are driving the variations of the net carbon balance. Table 2 further shows that NEP anomalies in the five defined regions 


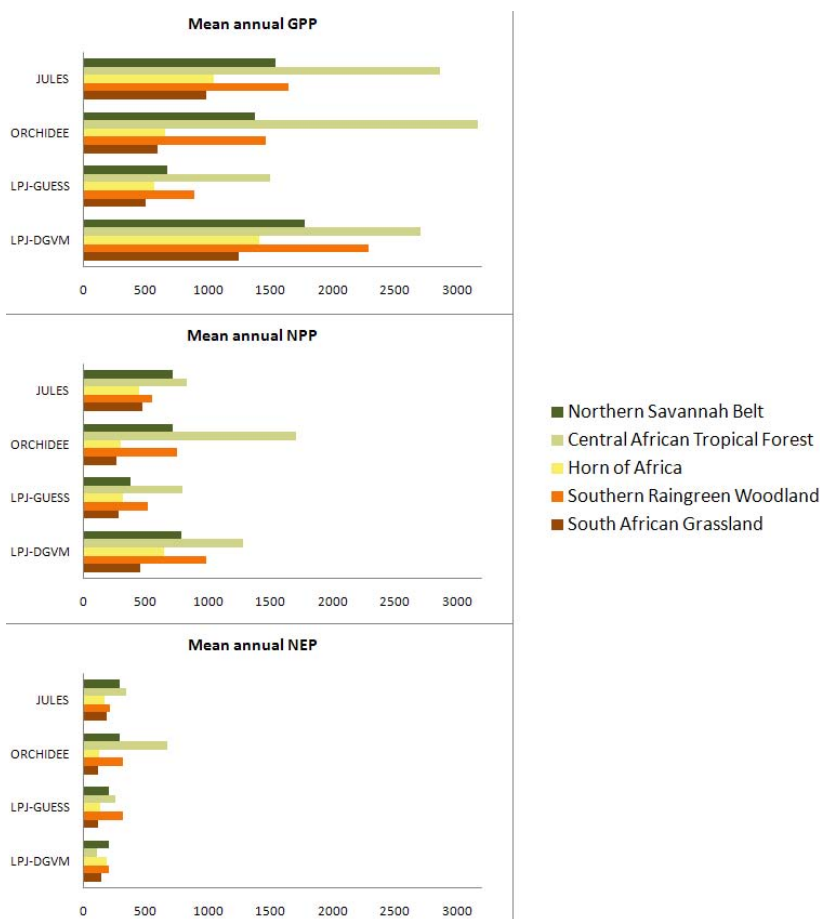

Fig. 3. Annual average GPP, NPP, and NEP per region ( $\left.\mathrm{g} \mathrm{C} / \mathrm{m}^{2} / \mathrm{yr}\right)$.

are strongly correlated with GPP anomalies in all models. In many cases anomalies of ecosystem respiration are also positively correlated with the NEP anomalies which may appear counterintuitive at first glance. If respiration would drive the carbon balance we would expect negative correlations; the positive correlations instead originate from the tight coupling of GPP and TER in the models, which is also evident in eddy-covariance based, estimates of GPP and TER (e.g. Reichstein et al., 2007; Baldocchi, 2008). In such case a positive anomaly of TER results in a positive anomaly of NEP because the GPP increase is even higher, than the (GPP induced) TER stimulation.

Although the overall pattern of GPP controlled NEP interannual variability is robust and consistent among models and regions, we find differences in the strength of this relationship depending on the model and region. JULES and LPJ-GUESS show strongest correlations between GPP and NEP anomalies $\left(\mathrm{R}_{\mathrm{GPP} / \mathrm{NEP}}>0.92\right)$ in all regions, while LPJDGVM and ORCHIDEE simulate larger inter-regional variability and slightly weaker correlations.

\section{The response of simulated gross primary production to meteorological conditions}

Having identified GPP as a crucial driver of the carbon balance and the hotspot regions of largest interannual variability in east and South Africa, we now infer which meteorological conditions drive the variability of GPP. We use a principal
Table 2. Correlation coefficient $(R)$ between GPP and NEP anomalies (left), and TER and NEP anomalies 1 (right) per region and model

\begin{tabular}{lll}
\hline Northern Savannah Belt & $\mathrm{R}(\mathrm{GPP} / \mathrm{NEP})$ & $\mathrm{R}$ (TER/NEP) \\
\hline LPJ DGVM & 0.71 & 0.19 \\
LPJ GUESS & 0.97 & 0.82 \\
ORCHIDEE & 0.83 & 0.67 \\
JULES & 0.99 & 0.99 \\
Central African tropical forest & $\mathrm{R}(\mathrm{GPP} / \mathrm{NEP})$ & $\mathrm{R}(\mathrm{TER} / \mathrm{NEP})$ \\
LPJ DGVM & 0.83 & 0.57 \\
LPJ GUESS & 0.92 & 0.67 \\
ORCHIDEE & 0.79 & 0.63 \\
JULES & 0.94 & 0.91 \\
Horn of Africa & $\mathrm{R}(\mathrm{GPP} / \mathrm{NEP})$ & $\mathrm{R}(\mathrm{TER} / \mathrm{NEP})$ \\
LPJ DGVM & 0.94 & 0.84 \\
LPJ GUESS & 0.99 & 0.92 \\
ORCHIDEE & 0.82 & 0.60 \\
JULES & 0.99 & 0.99 \\
Southern raingreen woodland & $\mathrm{R}(\mathrm{GPP} / \mathrm{NEP})$ & $\mathrm{R}(\mathrm{TER} / \mathrm{NEP})$ \\
LPJ DGVM & 0.89 & 0.64 \\
LPJ GUESS & 0.99 & 0.91 \\
ORCHIDEE & 0.47 & 0.12 \\
JULES & 0.96 & 0.93 \\
South African Grassland & $\mathrm{R}(\mathrm{GPP} / \mathrm{NEP})$ & $\mathrm{R}(\mathrm{TER} / \mathrm{NEP})$ \\
LPJ DGVM & 0.94 & 0.78 \\
LPJ GUESS & 1.00 & 0.96 \\
ORCHIDEE & 0.81 & 0.60 \\
JULES & 1.00 & 0.99 \\
\hline
\end{tabular}

Table 3. Eigenvectors and percent variance per Principal Component Modes

\begin{tabular}{llllll}
\hline Eigenvectors & precipitation & temp2m & iswrad & shumid & variance \% \\
\hline Mode 1 & 0.41 & 0.20 & -0.26 & 0.42 & 55.09 \\
Mode 2 & 0.00 & -0.79 & -0.61 & -0.01 & 25.19 \\
Mode 3 & -0.51 & 0.67 & -0.87 & -0.35 & 15.57 \\
Mode 4 & 1.67 & 0.14 & -0.15 & -1.79 & 4.14 \\
\hline
\end{tabular}

component analysis to reduce the dimensionality of the meteorological dataset and to extract typical weather gradients (see Sect. 2.4). The first two modes of the PCA of the annual meteorological data explain $80 \%$ of its variability (Table 3 ) and are used to infer the primary driving factor of GPP interannual variability in the models. The first mode is most strongly associated with precipitation and specific humidity and thus represents a gradient of moisture availability. The factor loadings of the second mode show that it represents a gradient of increasing temperature and radiation with decreasing values of mode 2 .

The correlation maps between the first principal component and GPP clearly show that moisture availability is the main limiting factor for photosynthesis (Fig. 8). This finding is in conjunction with Williams et al. (2008), who identified water stress as the primary governing factor of IAV 

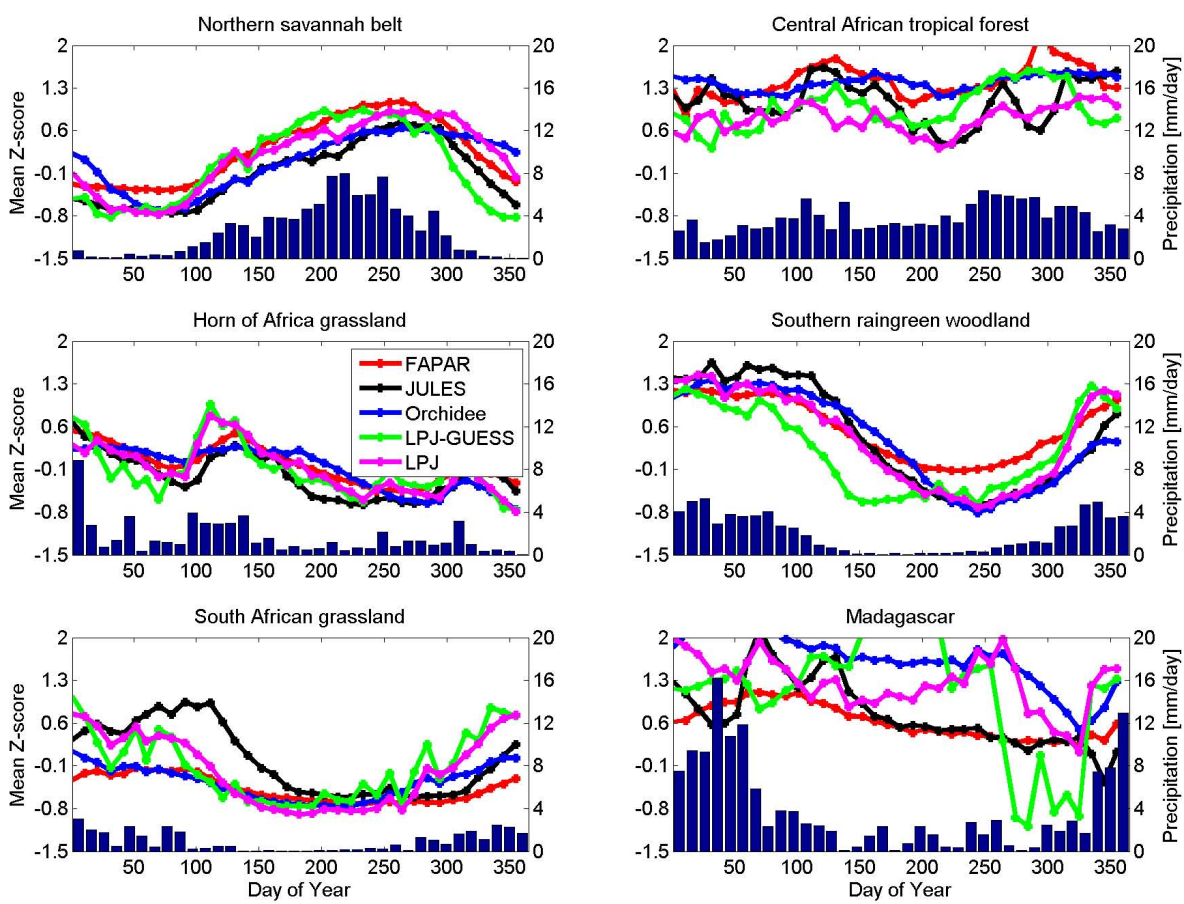

Fig. 4. Standardized mean seasonal cycle GPP from SEAWIFS-FAPAR and participating models.

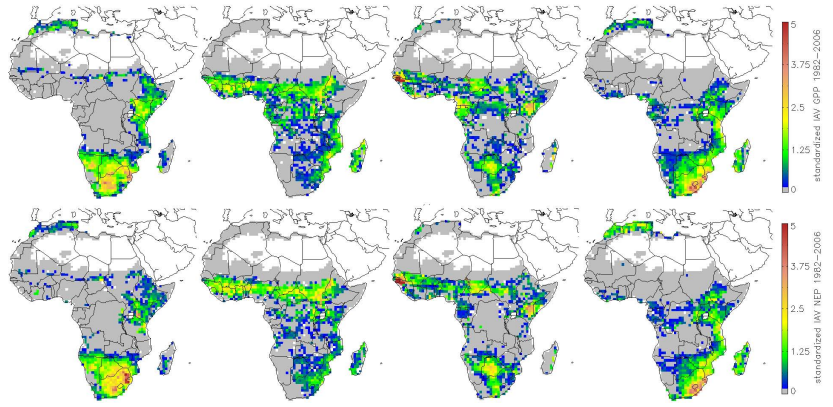

Fig. 5. Standardized interannual variability of modeled GPP (top), NEP (bottom); from left: LPJ-DGVM, ORCHIDEE, JULES, LPJGUESS.
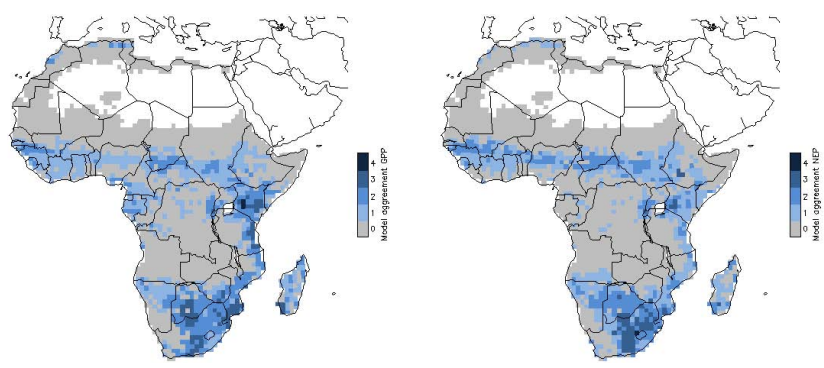

Fig. 6. Model agreement of interannual variability defined as count of models per grid cell where standardized interannual variability is greater than one standard deviation (GPP (left), NEP (right), 19822006)
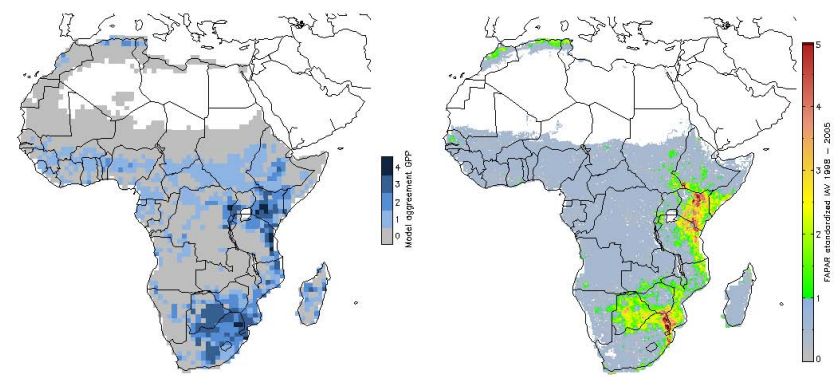

Fig. 7. GPP model agreement of interannual variability defined as count of models per grid cell where standardized interannual variability is greater than one standard deviation 1998-2005 (left), and standardized SeaWiFs-FAPAR interannual variability greater one standard deviation 1998-2005 (right)

of photosynthesis. Correlation maps between the meteorological PCAs and the mean annual FAPAR from SeaWiFS (Fig. 9) confirm that primary productivity responds to moisture in south and east Africa, which are the regions of largest interannual variability (see Sect. 3.2). The correlations between moisture and FAPAR on interannual scale in the Northern Savannah Belt are not as extensive as indicated by the models. This is possibly an artifact related to the relatively short time series ( 8 years) and coarse meteorological data. Camberlin et al. (2006) found more widespread strong correlations between integrated NDVI and rainfall for a 20 year time series in the northern savannahs. We also find no correlations between moisture and FAPAR in the Horn 


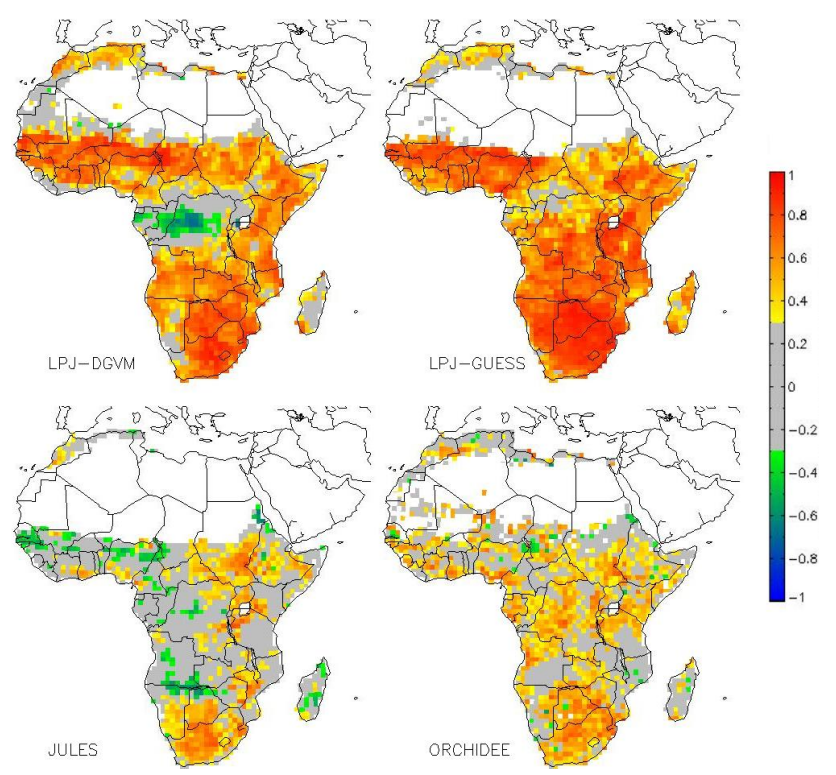

Fig. 8. Correlation between modeled GPP and Meteorology PCA 1 , not significant correlations in grey (confidence interval $=0.90$ )
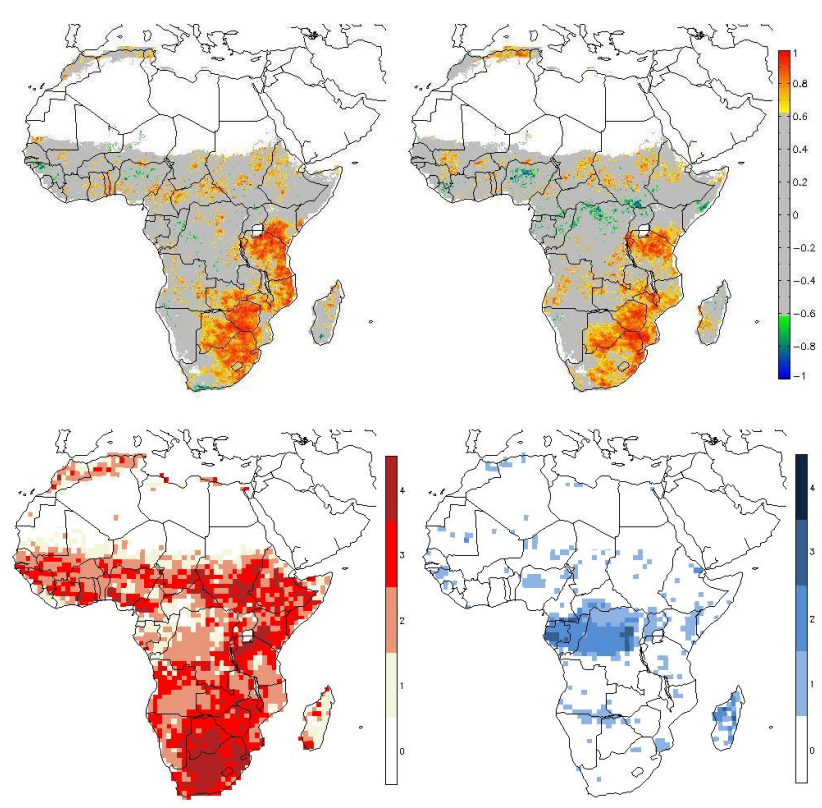

Fig. 9. Top: Correlation between FAPAR and Meteorology PCA 1 (left) and PCA 2 (right), not significant correlations in grey (confidence interval=0.90), bottom: Model Agreement of significant (confidence interval=0.90) positive correlations between PCA1 and GPP (left), and of significant negative correlations between PCA2 and GPP (right).

of Africa region while the models suggest such relationship. For this region Camberlin et al. (2006) confirm no correlation between precipitation and vegetation productivity for the northern corner of the African Horn but indicate strong correlations with rainfall in the southern part of the region.

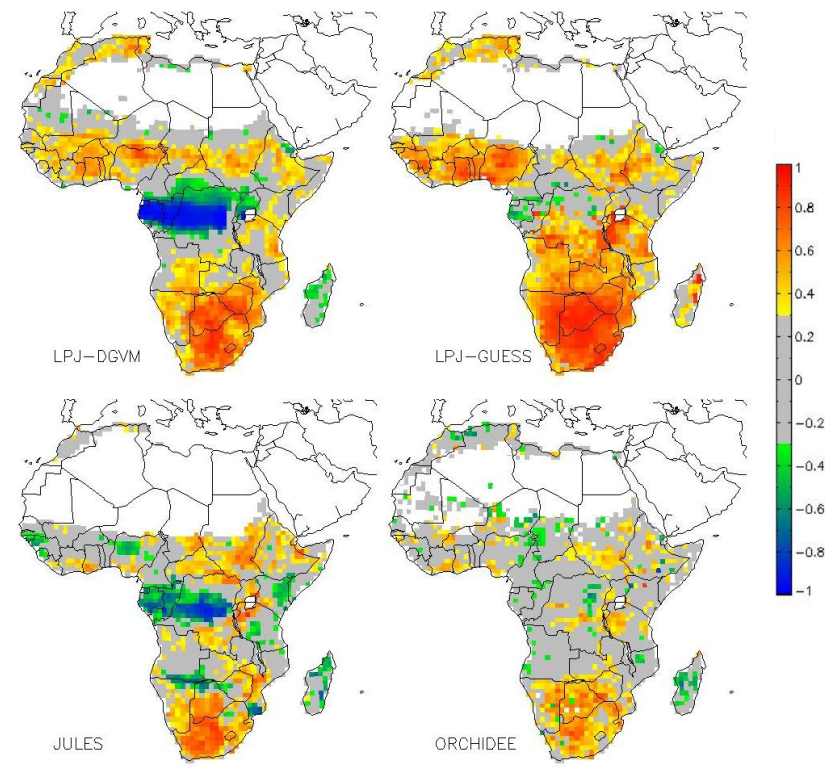

Fig. 10. Correlation between modeled GPP and Meteorology PCA 2 , not significant correlations in grey (confidence interval=0.90)

The partly different spatial correlation patterns between PCA1 and GPP among the models is likely related to different parameterizations for water stress effects such as root profiles, soil depth, and the coupling between photosynthesis and transpiration via canopy conductance which largely determines soil water depletion. The simulation of water stress effects on photosynthesis has been previously identified as a major source for differences among models regarding interannual variability of GPP in Europe (Jung et al., 2007; Vetter et al., 2008).

The general water limitation of African vegetation's primary production is consistent with Churkina and Running (1998) based on Biome-BGC simulations and Jolly et al. (2005) based on the analysis of remote sensing data from MODIS. Using a production efficiency model Nemani et al. (2003) find that tropical Africa is primarily radiation limited, while both Churkina and Running (1998) as well as Jolly et al. (2005) masked the inner tropical regions and concluded that no climatic constrain limits productivity here. Interestingly, LPJ-DGVM and JULES also suggest that not rainfall but radiation limits GPP in some regions, especially in the inner tropics. This is represented by the negative correlations between PCA 2 and GPP in the tropical forest where simulated GPP increases with increasing radiation and temperature (Fig. 10). Given that temperature limitation does likely not play a role here, we can interpret the negative correlations between PCA2 and GPP as an indication for light limitation. The latter also makes sense since frequent cloud cover is present in the tropics, which controls incoming radiation with otherwise favorable climatic conditions for productivity. Light limitation for parts of the Amazon tropical forests has been inferred from studying wet to 
dry season transitions using in-situ measurements of $\mathrm{CO}_{2}$ gas exchange (Saleska et al., 2003), manipulative experiments (Graham et al., 2002), and remote sensing based studies (Huete et al., 2006; Xiao et al., 2006; Nemani et al., 2003). Light limitation for parts of the Amazon result from access to groundwater during dry seasons when the vegetation capitalizes from the increases incoming radiation. From the correlation maps between the remote sensing based FAPAR and PCA2 we also find patches in the inner tropics of Africa where productivity increases with increasing radiation but to a much smaller extent than suggested by some of the models. Thus, the role of light availability in the African tropics remains controversial. There are several possible reasons why we find only small areas with significant correlation between radiation and productivity from the remote sensing data: (1) the short time series (8 years) in combination with small variances make it difficult to achieve large correlations, (2) the uncertainty of the meteorological data that originate from global reanalysis, (3) possible errors in the satellite FAPAR retrievals due to subpixel cloud contamination, (4) a strong role of non-climatic limitations of productivity such as nutrients. If nutrients are not most limiting, ecosystems are more sensitive to climatic variations. Possibly, light limitation in the African tropics occurs where less phosphorous depleted soils are present since phosphorous is believed to be generally the main limiting factor for productivity in the tropics (Vitousek, 1984). The overriding effect of nutrient availability may explain why we find only small areas with light limitation from the analysis using the satellite data, in contrast to the extensive areas of light limitation indicated by LPJ-DGVM, JULES, and Nemani et al. (2003) because none of the latter considers explicitly nutrient cycles.

\section{Conclusions}

Using four terrestrial ecosystem models in combination with remote sensing based information of vegetation productivity we were able to identify that (1) the largest interannual variability of gross primary production and net ecosystem productivity are concentrated in east and south Africa, (2) interannual variations of gross primary production is driving net ecosystem production in the models, and (3) the availability of moisture is the primary determinant of interannual variations of gross primary production and consequently the net carbon balance.

Nevertheless, our current simulations reveal substantial discrepancies among models regarding the actual flux magnitudes. Future simulations should be performed with improved forcings by prescribing the actual distribution of vegetation types provided by a remote sensing based land cover map and improved meteorological reanalysis. In addition it should be investigated to what extent the models are able to reproduce the ecological patterns found in the synthesis of insitu measurements of carbon and water fluxes across Africa
(Merbold et al., 2009). Given the significance of moisture control on the carbon fluxes in most parts of Africa, particular attention should be dedicated to the models' ability to accurately simulate soil hydrological conditions, and the sensitivity of photosynthesis and soil respiration to soil moisture.

Acknowledgements. The work was supported by the European Commission via the FP6 project CarboAfrica (EU, Contract No.: 037132). We thank Neil Hanan and Christopher Williams for their support on the experimental setup and implementation.

Edited by: F. Joos

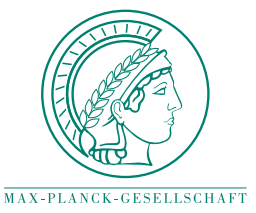

This Open Access Publication is financed by the Max Planck Society.

\section{References}

Anyamba, A., Tucker, C. J., and Mahoney, R.: From El Niño to La Niña: Vegetation Response Patterns over East and Southern Africa during the 1997-2000 Period, J. Clim., 15(21), 30963103, 2002

Anyamba, A., Justice, C. O., Tucker, C. J., and Mahoney, R.: Seasonal to interannual variability of vegetation and fires at SAFARI 2000 sites inferred from advanced very high resolution radiometer time series data, J. Geophys. Res., 108(D13), 8507, doi:10.1029/2002JD002464, 2003.

Baldocchi, D.: 'Breathing' of the terrestrial biosphere: lessons learned from a global network of carbon dioxide flux measurement systems, Australian J. Botany, 56, 1-26, 2008.

Camberlin, P., Martiny, N., Philippon, N., and Richar, Y.: Determinants of the interannual relationships between remote sensed photosynthetic activity and rainfall in tropical Africa. Remote Sens. Environ., 106(2), 199-216, 2006.

Cao, M. K., Zhang, Q. F., and Shugart, H. H.: Dynamic responses of African ecosystem carbon cycling to climate change, Clim Res., 17, 183-193, 2001.

Churkina, G. and Running, S.: Contrasting climatic controls on the estimated productivity of global terrestrial biomes, Ecosystems, 1, 206-215, 1998.

Ciais, P., Reichstein, M., Viovy, N., Granier, A., Oge'e, J., Allard, V., Aubinet, M., Buchmann, N., Bernhofer, Chr., Carrara A., Chevallier, F., De Noblet, N., Friend, A. D., Friedlingstein, P., Gruenwald, T., Heinesch, B., Keronen, P., Knohl, A., Krinner, G., Loustau, D., Manca, G., Matteucci, G., Miglietta, F., Ourcival, J. M., Papale, D., Pilegaard, K., Rambal, S., Seufert, G., Soussana, J. F., Sanz, M. J., Schulze, E. D., Vesala, T., and Valentini, R.: Europe-wide reduction in primary productivity caused by the heat and drought in 2003, Nature, 437, doi:10.1038/nature03972, 2005.

Collatz, G. J., Ball, J. T., Grivet, C., and Berry, J. A.: Physiological and environmental-regulation of stomatal conductance, photosynthesis and transpiration a model that includes a laminar boundary-layer, Agric. Forest Meteorol., 54(2-4), 107-136. 1991. 
Collatz, G. J., Ribas-Carbo, M., and Berry, J. A.: Coupled photosynthesis-stomatal conductance model for leaves of $\mathrm{C} 4$ plants, Aust. J. Plant Physiol., 19(5), 519-538, 1992.

Cox, P. M.: Description of the TRIFFID Dynamic Global Vegetation Model. Technical Note 24. Hadley Centre, Met Office, UK, 16, 2001.

Cramer, W., Kicklighter, D. W., Bondeau, A., Moore, B., Churkina, G., Nemry, B., Ruimy, A., and Schloss, A. L.: Comparing global models of terrestrial net primary productivity (NPP): overview and key results, Glob. Change Biol., 5, 1-15. 1999.

Cramer, W., Bondeau, A., Woodward, F. I., Prentice, I. C., Betts, R. A., Brovkin, V., Cox, P. M., Fisher, V., Foley, J., Friend, A. D., Kucharik, C., Lomas, M. R., Ramankutty, N., Sitch, S., Smith, B., White, A., and Young-Molling, C.: Global response of terrestrial ecosystem structure and function to $\mathrm{CO}_{2}$ and climate change: results from six dynamic global vegetation models, Glob. Change Biol., 7(4), 357-373. 2001.

Essery, R. L. H., Best, M. J., and Cox, P. M.: MOSES 2.2 Technical Documentation. Technical Note 30. Hadley Centre, Met Office, UK, 30, 2001.

Farquhar, G. D., von Caemmerer, S., and Berry, J. A.: A biogeochemical model of photosynthesis in leaves of $\mathrm{C} 3$ species. Planta, 149, 78-90, 1980.

Fekete, B. M., Vörösmaty, C. J., Roads, J.O., and Willmott, C. J.: Uncertainties in Precipitation and Their Impacts o Runoff Estimates, J. Climate, 17, 294-304. 2003.

Friedlingstein, P., Cox, P., Betts, R., Bopp, L., Von Bloh, W., Brovkin, V., Cadule, P., Doney, S., Eby, M., Fung, I., Bala, G., John, J., Jones, C., Joos, F., Kato, T., Kawamiya, M., Knorr, W., Lindsay, K., Matthews, H. D., Raddatz, T., Rayner, P., Reick, C., Roeckner, E., Schnitzler, K. G., Schnur, R., Strassmann, K., Weaver, A. J., Yoshikawa, C., and Zeng, N.: Climate-carbon cycle feedback analysis: Results from the (CMIP)-M-4 model intercomparison, J. Clim., 19, 3337-3353, 2006.

Foley, J. A., Prentice, I. C., Ramankutty, N., Levis, S., Pollard, D., Sitch, S., and Haxeltine, A.: An integrated biosphere model of land surface processes, terrestrial carbon balance and vegetation dynamics, Global Biogeochem. Cy., 10( 4), 603-628, 1996.

Gobron, N., Pinty, B., Verstraete, M. M., and Widlowski, J.-L.: Advanced vegetation indices optimized for up-coming sensors: Design, performance, and applications, Geosci. Remote Sens., 38(6), 2489-2505, 2000.

Gobron, N., Pinty, B., Mélin, F., Taberner, M., Verstraete, M. M., Belward, A., Lavergne, T., and Widlowski, J.-L.: The state of vegetation in Europe following the 2003 drought, Int. J. Remote Sens. Lett., 26, 2013-2020, 2005.

Graham, F. A., Mulkey, S. S., Kitajima, K., Phillips, N. G., and Wright, S. S.: Cloud cover limits net $\mathrm{CO}_{2}$ uptake and growth of a rainforest tree during tropical rainy seasons, PNAS, 100(2), 572-576, 2003.

Green, G. M. and Sussman, R. W.: Deforestation history of the eastern rain forests of Madagascar from satellite images, Science, 248, 212-215, 1990.

Huete, A. R., Didan, K., Shimabukuro, Y. E., Ratana, P., Saleska, S. R., Hutyra, L. R., Yang, W., Nemani, R. R., and Myneni, R.: Amazon rainforests green-up with sunlight in dry season, Geophys. Res. Lett., 33, L06405, doi:10.1029/2005GL025583, 2006

Hughes, J. K., Valdes, P. J., and Betts, R.: Dynamics of a globalscale vegetation model, Ecol. Model., 198(3-4), 452-462, 2006.
IPCC 2007: Climate Change 2007: The Physical Science Basis. Contribution of Working Group I to the Fourth Assessment Report of the Intergovernmental Panel on Climate Changem, edited by: Solomon, S., Qin, D., Manning, M., Chen, Z., Marquis, M., Averyt, K. B., Tignor, M., and Miller, H. L., Cambridge University Press, Cambridge, UK and New York, NY, USA.

Jung, M., Vetter, M., Herold, M., Churkina, G., Reichstein, M., Zaehle, S., Cias, P., Viovy, N., Bondeau, A., Chen, Y., Trusilova, K., Feser, F., and Heimann, M.: Uncertainties of modelling GPP over Europe: A systematic study on the effects of using different drivers and terrestrial biosphere models, Global Biogeochem. Cy., 21, GB4021, doi:10.1029/2006GB002915, 2007.

Jung, M., Verstraete, M., Gobron, N., Reichstein, M., Papale, D., Bondeau, A., Robustelli, M., and Pinty, B.: Diagnostic assessment of European gross primary production, Global Change Biology, 14, 1-16, doi:10.1111/j.1365-2486.2008.01647.x, 2008.

Jolly, W., Nemani, R., and Running, S. W.: A generalized, bioclimatic index to predict foliar phenology in response to climate, Global Change Biol., 11, 619-632, doi:10.1111/j.13652486.2005.00930.x, 2005.

Kalnay, E., Kanamitsu, M., Kistler, R., Collins, W., Deaven, D., Gandin, L., Iredell, M., Saha, S., White, G., Woollen, J.Zhu, y., Chelliah, M., Ebisuzaki, W., Higgins, W., Janowiak, J., Mo, K.C., Ropelewski, C., Wang, J., Leetmaa, A., and Reynolds, R.: The NCEP/NCAR 40-year reanalysis project, B. Amer. Meteor. Soc., 77, 437-470, 1996.

Kanamitsu, M., Ebisuzaki, W., Woollen, J., Yang, S.-K., Hnilo, J. J., Fiorino, M., and Potter, G. L.: NCEP-DEO AMIPII Reanalysis (R-2), B. Atmos. Meterol. Soc., 1631-1643, doi:10.1175/BAMS-83-11-1631, November 2002.

Kistler,R., Kalnay, E., Collins,W., Saha,S., White,G., Woollen,J., Chelliah, M., Ebisuzaki, W., Kanamitsu, M., Kousky, V., van den Dool, H., Jenne, R., and Fiorino, M.: The NCEP-NCAR 50Year Reanalysis: Monthly Means CD-ROM and Documentation. B. Am. Meteorol. Soc., 82, 247-267. 2001.

Kogan, F. N.: Satellite - Observed Sensitivity of World Land Ecosystems to El Niño/La Niña, Remote Sens. Environ., 74, 445-462, 2000.

Krinner, G., Viovy, N., de Noblet-Ducoudre, N., Ogee, J., Polcher, J., Friedlingstein, P., Ciais, P., Stitch, S., and Prentice, C.: A dynamic global vegetation model for studies of the coupled atmosphere biosphere system, Global Biogeochem. Cy., 19, GB1015, doi:10.1029/2003GB002199. 2005.

Kummerow, C., Barnes, W., Kozu, T., Shiue, J., and Simpson, J.: The Tropical Rainfall Measuring Mission (TRMM) sensor package, J. Atmos. Ocean. Tech., 15, 809-817, 1998.

Le Page, Y., Pereira, J. M. C., Trigo, R., Da Camara, C., Oom, D., and Mota, B.: Global fire activity patters (1996-2006) and climatic influence: an analysis using the World Fire Atlas, Atmos. Chem. Phys., 8, 1911-1924, 2008, http://www.atmoschem-phys.net/8/1911/2008/.

Linacre, E. T.: Net Radiation to Various Surfaces, J. Appl. Ecol., 6(1), 61-75, 1969.

Lloyd, J. and Taylor, J. A.: On the temperature dependence of soil respiration, Funct. Ecol. 8, 315-323, 1994.

McGuire, A. D., Sitch, S., Clein, J. S., Dargaville, R., Esser, G., Foley, J., Heimann, M., Joos, F., Kaplan, J., Kicklighter, D. W., Meier, R. A., Melillo, J. M., Moore, B., Prentice, I. C., Ramankutty, N., Reichenau, T., Schloss, A., Tian, H., Williams, 
L. J., and Wittenberg, U.: Carbon balance of the terrestrial biosphere in the twentieth century: Analyses of $\mathrm{CO}_{2}$, climate and land use effects with four process-based ecosystem models, Global Biogeochem. Cy., 15, 183-206, 2001

Mitchell, T. D. and Jones, P. D.: An improved method of constructing a database of monthly climate observations and associated high-resolution grids, Int. J. Climatol., 25, 693-712, doi:10.1002/joc.1181, 2005.

Morales, P., Sykes, M. T., Prentice, I. C., Smith, P., Smith, B., Bugmann, H., Zierl, B., Friedlingstein, P., Viovy, N., Sabaté, S., Sánchez, A., Pla, E., Gracia, C. A., Sitch, S.,Arneth, A., and Ogee, J.: Comparing and evaluating process-based ecosystem model predictions of carbon and water fluxes in major European forest biomes, Global Change Biol., 11, 1-23, 2005.

Myneni, R. B., Los, S. O., and Tucker, C. J.: Satellite based identification of linked vegetation index and sea surface anomaly areas from 1982-1990 for Africa, Australia and South America, Geophys. Res. Lett., 23(7), 729-732, 1996.

Nemani, R. R., Keeling, C. D., Hashimoto, H., Jolly, W. M., Piper, S. C., Tucker, C. T., Myneni, R. B., and Running, S. W.: Climate-Driven Increases in Global Terrestrial Net Primary Production from 1982 to 1999, Science, 300, 5625, doi:10.1126/science.1082750, 2003.

Ngo-Duc, T., Polcher, J., and Laval, K.: A 53-year data set for land surface models, J. Geophy.Res., 110, D06116, doi:101029/2004JD005434, 2005.

Plisnier, P. D., Serneels, S., and Lambin, E. F.: Impact of ENSO on East African ecosystems: a multivariate analysis based on climate and remote sensing data, Global Ecol. Biogeogr., 9, 481497, 2000.

Potter, C. S., Klooster, S., and Brooks, V.: Interannual variability in terrestrial net primary production: Exploration of trends and controls on regional to global scales, Ecosystems, 2, 36-48, 1999.

Potter, C., Klooster, S., Myneni, R., Genovese, V., Tan, P.-N., and Kumar, V.: Continental-scale comparisons of terrestrial carbon sinks estimated from satellite data and ecosystem modeling 1982-1998, Glob. Planet. Change, 39, 201-213, 2003.

Randerson, J. T., van der Werf, G. R., Giglio, L., Collatz, G. J., and Kasibhatla, P. S.: Global Fire Emissions Database, Version 2 (GFEDv2.1), Data set, available online: http://daac.ornl.gov/ from Oak Ridge National Laboratory Distributed Active Archive Center, Oak Ridge, Tennessee, USA, 2007.

Reichstein, M., Papale, D., Valentini, R., Aubinet, M., Bernhofer, C:, Knohl, A., Laurila, T., Lindroth, A., Moors, E., Pilegaard, K., and Seufert, G.: Determinants of terrestrial ecosystem carbon balance inferred from European eddy covariance flux sites, Geophys. Res. Lett., 34, L01402262, doi:10.1029/2006GL027880, 2007.

Rödenbeck, C.: Estimating $\mathrm{CO}_{2}$ sources and sinks from atmospheric mixing ratio measurements using a global inversion of atmospheric transport. Technical Report 6, Max Planck Institute for Biogeochemistry, Jena, 61, 2005.

Saleska, S. R., Miller, S. D., Matross, D. M., Goulden, M. L., Wofsy, S. C., Da Rocha, H. R., De Camargo, P. B., Crill, P., Daube, B. C., De Freitas, H. C., Hutyra, L., Keller, M., Kirchhoff, V., Menton, M., Munger, J. W., Hammond Pyle, E., Rice, A. H., and Silva, H.: Carbon in Amazon Forest: Unexpected Seasonal Fluxes and Disturbance - Induced Losses. Science, 302, 1554-1557, 2003.
Sheffield, J., Goteti, G., and Wood, E. F.: Development of a 50-year High Resolution Global Dataset of Meteorological Forcings for Land Surface Modeling, J. Clim., 19, 3088-3110, 2006.

Sitch, S., Smith, B., Prentice, I. C., Arneth, A., Bondeau, A., Cramer, W., Kaplan, J. O., Levis, S., Lucht, W., Sykes, M. T., Thonicke, K., and Venevsky, S.: Evaluation of ecosystem dynamics, plant geography and terrestrial carbon cycling in the LPJ dynamic global vegetation model, Glob. Change Biol., 9, 161$185,2003$.

Smith, T. M., Shugart, H. H. and Woodward, F. I. (Eds.): Plant Functional Types, Cambridge University Press, Cambridge, 1997.

Smith, B., Prentice, I. C., and Sykes, M. T.: Representation of vegetation dynamics in the modelling of terrestrial ecosystems: comparing two contrasting approaches within European climate space, Global Ecol. Biogeogr., 10, 621-637, 2001.

Shugart, H. H.: A Theory of Forest Dynamics: The Ecological Implications of Forest Succession Models, Springer-Verlag, New York, USA, 1984.

Tempel, P., Batjes, N. H., Collaty, G. J., and van Engelen, V. W. P.: IGBP-DIS soil data set for pedotransfer function development, Working paper and Reprint 96/05, International Soil Reference and Information Centre (ISRIC), Wageningen, 1996.

TRMM 3B43- Tropical Rainfall Measuring Mission Science Data and Information System (TSDIS) Interface Control Specification: ftp://disc2.nascom.nasa.Gov/data/TRMM/Gridded/3B43_ V6/, last access: 31 May 2007.

Thonicke, K., Venevsky, S., Sitch, S., and Cramer, W.: The role of fire disturbance for global vegetation dynamics: coupling fire into a Dynamic Global Vegetation Model, Global Ecol. Biogeogr., 10, 661-677, 2001.

Van der Werf, G. R., Randerson, J. T., Giglio, L., Collatz, G. J., and Kasibhatla, P. S.: Interannual variability in global biomass burning emission from 1997 to 2004, Atmos. Chem. Phys., 6, 3423-3441. 2006.

Vetter, M., Churkina, G., Jung, M., Reichstein, M., Zaehle, S., Bondeau, A., Chen, Y. H., Ciais, P., Feser, F., Freibauer, A., Geyer, R., Jones, C., Papale, D., Tenhunen, J., Tomelleri, E., Trusilova, K., Viovy, N., and Heimann, M.: Analyzing the causes and spatial pattern of the European 2003 carbon flux anomaly using seven models, Biogeosciences, 5, 561-583, 2008, http://www.biogeosciences.net/5/561/2008/.

Vitousek, M.: Litterfall, Nutrient Cycling, and Nutrient Limitation in Tropical Forests, Ecology, 65, 285-298, 1984.

Williams, C. W., Hanan, N. P., Neff, J. C., Scoles, R. J., Berry, J. A., Denning, A. S., and Baker, D. F.: Africa and the global carbon cycle, Carbon Balance and Management, 2:3, doi:10.1186/17500680-2-3, 2007.

Williams, C. A., Hanan, N. P., Baker, I., Collatz, G. J., Berry, J., and Denning, A. S.: Interannual variability of photosynthesis across Africa and its attribution, J. Geophys. Res., 113, G04015, doi:10.1029/2008JG000718, 2008.

Xiao, X., Hagen, S., Zhang, Q., Keller, M., and Moore III, B.: Detecting leaf phenology of seasonally moist tropical forests in South America with multi-temporal MODIS images, Remote Sens. Environ., 103, 465-473, 2006.

Trends in Atmospheric Carbon Dioxide - Mauna Loa: www.esrl. noaa.gov/gmd/ccgg/trends/, access: 12 July 2007. 